\title{
Assessment of the Effects of Deforestation on Springs: A Case Study of Nuu/Mutaitho Hills Springs in Kitui County
}

\author{
Rose Catherine Mwia John ${ }^{1}$, Johnson U. Kitheka ${ }^{2}$, Moses Mwangi ${ }^{3}$ \\ ${ }^{1}$ Tanathi Water Services Board, K.I.D.P.Building,Kalawa Rd,Private bag,Kitui, Kenya \\ ${ }^{2}$ School of Water Resources and Technology, South Eastern Kenya University, P.O Box 170-90200 Kitui, Kenya \\ ${ }^{3}$ Department of Hydrology and Water Resources Management, School of Water Resources and Technology \\ South Eastern Kenya University, P.O Box 170-90200 Kitui, Kenya
}

\begin{abstract}
Nuu/Mutaitho springs in the arid and semi-arid Kitui County in Eastern Kenya are important sources of water for communities and livestock. In the recent past, there has been significant reduction in the discharges of springs in the area. The deforestation of Nuu/Mutaitho hills is thought to be main cause of this reduction. Therefore, this study sought to determine the main causes of decline in spring discharges in Nuu and Mutaitho Hills. Attempt was made in the study to establish the relationship between spring discharges, rate of deforestation and rainfall variability. The study also involved determination of the impacts of decreasing spring discharges and examination of the perceptions of the local communities on the causes of decline in spring discharges. The data was analyzed using the Statistical Package for the Social Sciences (SPSS), Geographical Information system (GIS) and various Microsoft Excel statistical tools. The results of the study show that annual rainfall in the Nuu hills is exhibiting significant seasonal and inter-seasonal variations and the spring discharges have decreased by $30 \%$. The annual total rainfall amount has also decreased from $800 \mathrm{~mm}$ to around $700 \mathrm{~mm}$ per annum. The analysis of land use/land cover change using Moderate Resolution Imaging Spectroradiometer (MODIS) showed that the dry lands forest cover has decreased by almost $40 \%$ with the current forest cover in the area being about $6 \%$. The main cause of the decrease in the forest cover is mainly anthropogenic activities particularly burning and opening land for various purposes, illegal harvesting of trees for timber and charcoal production and high rates of livestock grazing. The study recommends implementation of a comprehensive awareness creation campaign focusing on conservation of the Nuu/Mutaitho hill forests. There is also a need for enforcement of forest regulations in order to protect the forests. This will ensure sustained spring flows in the area.
\end{abstract}

Keywords: Deforestation, spring discharges, rainfall variability, MODIS, Nuu/Mutaitho hills, Kitui, Kenya

\section{Introduction}

This study is on the assessment of the effects of deforestation on semi-arid lands springs found in the semiaridKitui County in Eastern Kenya. In semi-arid regions of Kitui, springs are found on the forested slopes of high mountains and hills such as those in Nuu region. These springs are thought to emanate from unconfined aquifers on the hills and are important sources of water for rural communities in the Nuu region. The springs in area are drying rapidly and the main causes according to some studies are thought to be due to climate change particularly changes in rainfall amount and intensity, reduction in the spatial-temporal distribution of rainfall and a marked decline in the total annual rainfall, coupled with other anthropogenic causes (Tambe et al., 2012). The reduction in spring flows has led to reduction of base-flow in seasonal rivers emanating from Nuu Hills. This in turn has reduced the availability of water for both domestic and livestock use.

The Nuu springs have being sources of water for the people of Nuu area for a long time. In 1950s, the British colonial government gazetted part of the hill in order to protect the springs which were drying up due to the human settlements (Imbernon, 1999). However, after Kenya's independence in 1963, local community started encroaching on the hills and by the year 2000, a high percentage of the catchment had already been settled. The increased settlements on the hills has led to increased rate of deforestation and soil erosion. This is thought to have subsequently interfered with the recharge of springs due to degradation of the recharge areas and this may have led to progressive drying-up of the springs. Before the year 1980, the hilltops were not highly inhabited, and therefore the forest cover provided the ideal conditions for proper recharge of the ground water aquifers in the area.

The impacts of past, present, and future deforestation effects mostly caused by land use changes have been investigated by numerous studies (Brovkin, et. al., 2006, House et. al., 2002, Goudie, 2013). These studies have established that, the deforestation process primarily effects rainfall patterns and springs production. Previous studies have shown that Kitui County in general had many springs that were flowing from the semi-arid hills (Gachari, et al, 2011). This was due to the fact that most of the hills which are sources of springs were intact with very low rate of human encroachment Currently, the springs are diminishing rapidly due to degradation of the catchment areas (County MWI, 2016). Despite incremental improvements in our ability to quantify rates of forest clearing, there is still no definitive understanding of the extent of degradation of Nuu hills forests which are sources of springs found within the region. There is a need for this kind of research in order to guide formulation of policies aimed at addressing the root causes of forest degradation in Nuu Hills region (Pellikka et, al., 


\section{International Journal of Science and Research (IJSR) \\ ISSN (Online): 2319-7064 \\ Index Copernicus Value (2015): 78.96 | Impact Factor (2015): 6.391}

2009).The Nuu and Mutaitho hills springs are life-saving oasis in the arid and semi-arid Lands (ASAL) region of Eastern Kenya and there is a need to protect them in order to safeguard water supplies for people, wildlife and livestock. The role of forest conservation in sustaining water supplies has been demonstrated in studies that have been undertaken elsewhere (Pellikka, 2009). The interaction of forests and water resources is the most critical issue that must be accorded the highest priority because it impacts on the flow of both streams and springs (Laws, 1970). Rapid increase in human population including high demand for fuel wood and other forest products affects water availability in different parts of the world (UNEP, 2006). Over the past decades, terrestrial water flows have been affected by humans at an unprecedented scale and the rate of forest cover degradation is on the rise in most parts of the world (UNEP, 2006).Thus, this study focused on establishing the main factors that are causing the decline in spring flows in the semi-arid Nuu/Mutaitho hills in the semi-arid Kitui County in Eastern Kenya.

\section{The Study Area}

The Nuu Hills are found in Mwingi Sub-county, which is in Kitui County in Eastern Kenya. The study area is located $200 \mathrm{~km}$ east of Nairobi -Kenya's capital city. The Nuu and Mutaitho hills catchment area cover a surface area of with approximately $3,532 \mathrm{~km}^{2}$ and $2,170 \mathrm{~km}^{2}$, respectively and are the source of 13 springs (Avanloon, 2009) some of which shows evidence of declining flows. The springs lie at an altitude ranging from $650 \mathrm{~m}$ to $1,160 \mathrm{~m}$ ASL (above sea level) and within latitudes $37 \mathrm{~m} \mathrm{429000/37m} 420000$ and
SS9888000/9875000 Universal Transverse Mercator (UTM). The average rainfall received in the region ranges from 250 to $850 \mathrm{~mm}$ per annum with a very low reliability level in some areas (Berry, 2003). The Nuu hills region is also generally characterized by hot and dry climate with unreliable rainfall and erratic seasonal stream flows. The maximum mean annual temperature ranges between $260^{\circ} \mathrm{C}$ and $340^{\circ} \mathrm{C}$ and the mean annual potential evaporation rates range from 2000 to $2200 \mathrm{~mm}$ (Berry, 2003). The region has two rainy seasons falling in the period between April and May (long rains) and November-December (short rains). The two rainy seasons are unreliable and therefore surface water sources are scarce. People in the Nuu region are heavily dependent on springs (throughout the year) and seasonal rivers for water supply. Therefore, water shortages for domestic use and small scale irrigation farming in Nuu ward is a serious problem especially during the long dry spells which run from May to November. During the dry period, people tend to converge at the Nuu springs to scramble for the little remaining flow from the springs. Nuu location where the two hills are have an approximate total population of 24,850 persons according to the report of Kenya National Bureau of Statistics (2009). With the current population growth rate of $2.1 \%$ annually, the population of Nuu region was projected to be 28,502 by end of 2016 (Aremde et al., 2012; WRI, 2007). The population pattern in the study area is largely affected by the land ownership and land holding and also majorly by the fertility of the soils and the accessibility to water sources. The population density ranges from 25 persons per $\mathrm{Km}^{2}$ to 44 persons per $\mathrm{Km}^{2}$ (National Bureau of statistics 2007).

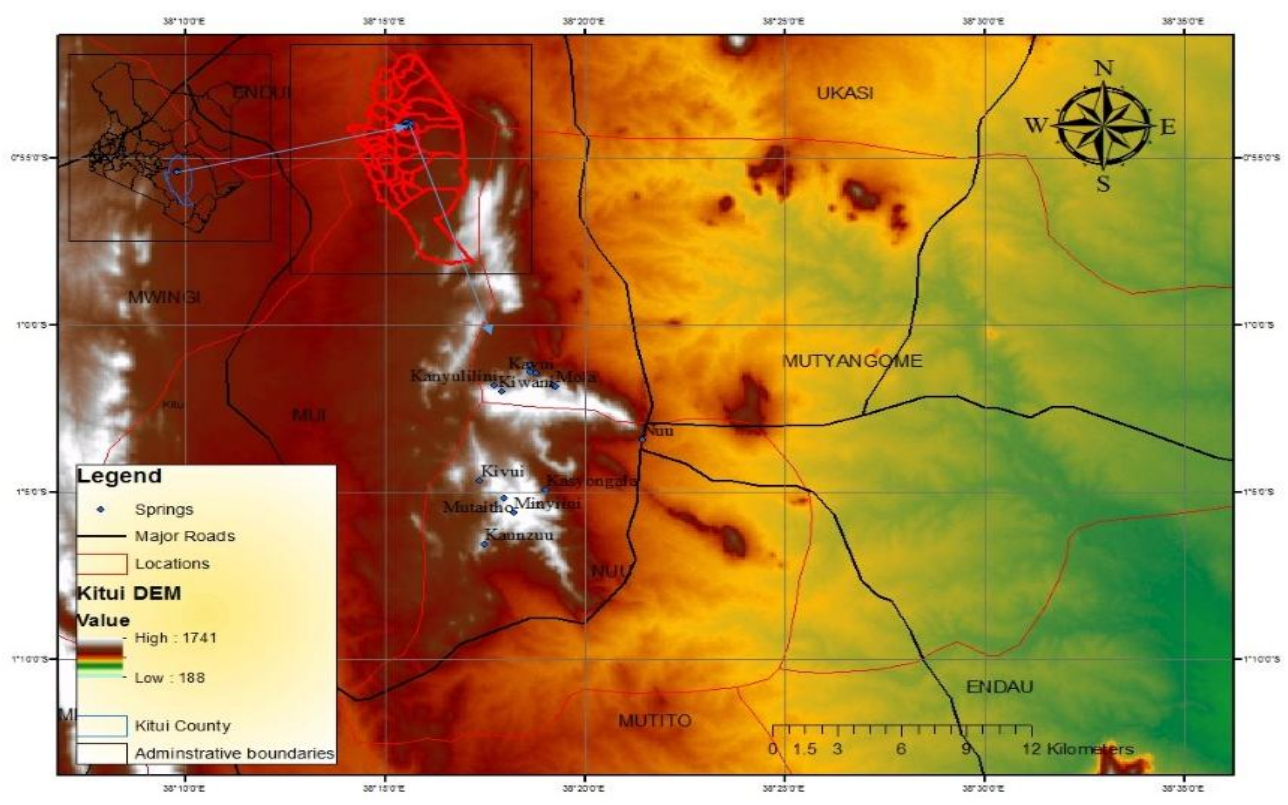

Figure 1: The location of Nuu/Mutaitho Hills in Kitui County in Eastern Kenya

\section{Methodology}

\section{a) Research Design}

In this study, data was obtained through questionnaire surveys and field data collection including also from the secondary data sources such as the technical reports. The primary data was obtained through personal interviews and field observations.

\section{b) Field Survey}

Field survey was conducted in order to familiarize with the area of study and the local conditions in the area. This also allowed the authors to have a general image of the study

\section{Volume 6 Issue 1, January 2017




\section{International Journal of Science and Research (IJSR) \\ ISSN (Online): 2319-7064}

Index Copernicus Value (2015): 78.96 | Impact Factor (2015): 6.391

area and also to find out the key hydrologic parameters in the area prior to the proposed research works. The survey also enabled the authors to a good understanding of the economic and land use activities in the study area.

\section{c) Methods of data collection}

The primary data included data on spring discharges, rainfall, deforestation rates and water abstraction rates. Methods that were applied in data collection are as follows.

\section{- Field Observations}

The field observations were used to capture the main activities in the study area. Satellite data was also used to determine the extent and rates of deforestation (cf. Brown et al., 2007; Hansen et al., 2013; Lefsky et al., 2002). Reprocessing of data offered a number of improvements on data quality and allowed for more flexible analyses (cf. Brown et al., 2007). A long time series of 20years provided more temporal context for cleared areas, and more data increase the likelihood of proper classification.

\section{- Questionnaire Surveys}

Questionnaires were administered using random sampling technique in order to sample the respondents. A questionnaire was also developed for institutions or organizations that exists in the study area to obtain data and information of the relationship between forests and water resource within the study area. Also, questionnaire was administered to individual households residing in the study area, especially those who reside in the proximity of the springs. Using this approach, we were able to capture the views of the people on the causes of deforestation in the catchment and decline of spring flows. The sample size dictated the number of persons that were interviewed in the study area. The population sample size was determined through the use of the equation 1 (John, 2003).

$$
n=\frac{z 2 p q}{d 2} \text {----------- Equation } 1
$$

Where;

$\mathrm{n}=$ is research minimum desired sample size

$\mathrm{z}=$ is standard normal deviate at required confidence level. Correspond to (1.96)

$p=20 \%$, is the proportion of the target population estimated to be aware of the effects of deforestations.

The population sample size was 62 persons. This was consistent with Mugenda (1990) who noted that the sample size has to be more than 30 persons for the results to be statistically significant. The respondents of the study were identified from households and informants that are spread within the Nuu location. The sample size obtained was proportionately allocated based on the number of households within the study area. Out of the 62 questionnaires that were administered, 10 questionnaires were administered to informants while the 52 questionnaires were administered to household heads.

\section{- Field Based Measurements}

The old spring discharge records were obtained from data archived by the community management teams. The spring discharges were also measured on site using a 20 litre jerican and a stop watch to time the time taken to fill the 201 jerican with spring's water. Discharge was calculated using equations 2 and 3.

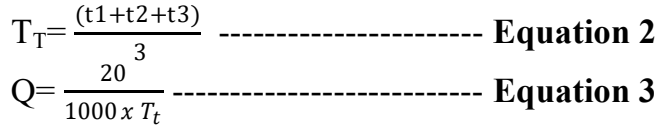

Where: $\mathrm{T}$ is the time taken for a 20 litre jerican to fill in seconds; $T_{t}$ is the average time taken for a 20 litre jerican to fill in seconds; $Q$ is the discharge calculated which is in $\mathrm{m}^{3} / \mathrm{s}$. The measurements were done both during the rainy season when the discharge was highest and in the dry season when the flows are lowest.

\section{- Determination of land use and vegetation cover changes}

Land use and forest cover changes were determined by use of the Moderate-resolution Imaging Spectroradiometer (MODIS) instruments (see Justice et al. 1998) which provided a unique resource for this study. The Satellite image data were downloaded from the USGS website (www.usgs.gov/dowloads). The download data included satellite images and the Moderate Resolution Imaging Spectroradiometer (MODIS) and Google earth data. The Google earth data showed the aerial imageries of the study area in different times and is mostly concentrated on vegetation cover of the study area. MODIS Tool was used to automate the process of data downloading and processing area, within a stipulated time periods, and the MODIS products receipt are the smart mosaic decorated maps (Chawla et al. 2012), which shows different characteristics of vegetation within the study area. This automation reduces the risk of human error, and the researcher effort required comparison to manual per-location downloads. By use of that mosaic decorated maps of different times, the author was able to study the characteristics of the vegetation in different times.

\section{- Rainfall data}

Secondary data was acquired from the pre-existing records from the relevant government institutions. The rainfall data was collected from the Water Resources Management Authority (WARMA) and Kenya Metrological Department (KMD)in Kitui. Unpublished data and information on the Nuu catchment was obtained from Kitui County government offices and Water Resources Management Authority (WARMA)in Kitui regional offices.

\section{Method of Data Analysis}

The data collected were analyzed using the Statistical Package for the Social Sciences (SPSS) and Microsoft Excel statistical package. Quantitative data was coded, processed and analyzed by use of Statistical Package for the Social Sciences (SPSS) and Ms. Excel. Various quantitative statistical methods that were used including arithmetic mean, regression and correlation. Those are described in the following sections. 


\section{International Journal of Science and Research (IJSR) \\ ISSN (Online): 2319-7064 \\ Index Copernicus Value (2015): 78.96 | Impact Factor (2015): 6.391}

\section{Results}

a) Relationship between spring discharge and rainfall Rainfall data obtained from Kenya Meteorological Department for Nuu location showed that there is a significant variations in the average rainfall within the study area (Figures 2 and 3). The rainfall trend in the Nuu region for the period between 1981 and 2015 (22 years) shows a significant trend. There was an increase in rainfall amount received in Nuu region from 1987 to 1998 . The high rainfall that was received in the period between 1997 and 1998 was due to the Southern Oscillation El-Nino phenomena (FAO, 2006). However, there was a decline in the total annual rainfall the period between 1998 and 2002 (Figures 3 and 4). Time series analysis of the total annual rainfall in Nuu region for the period between 1980 to 2015 also showed a decreasing trendthat can be attributed to climate change.

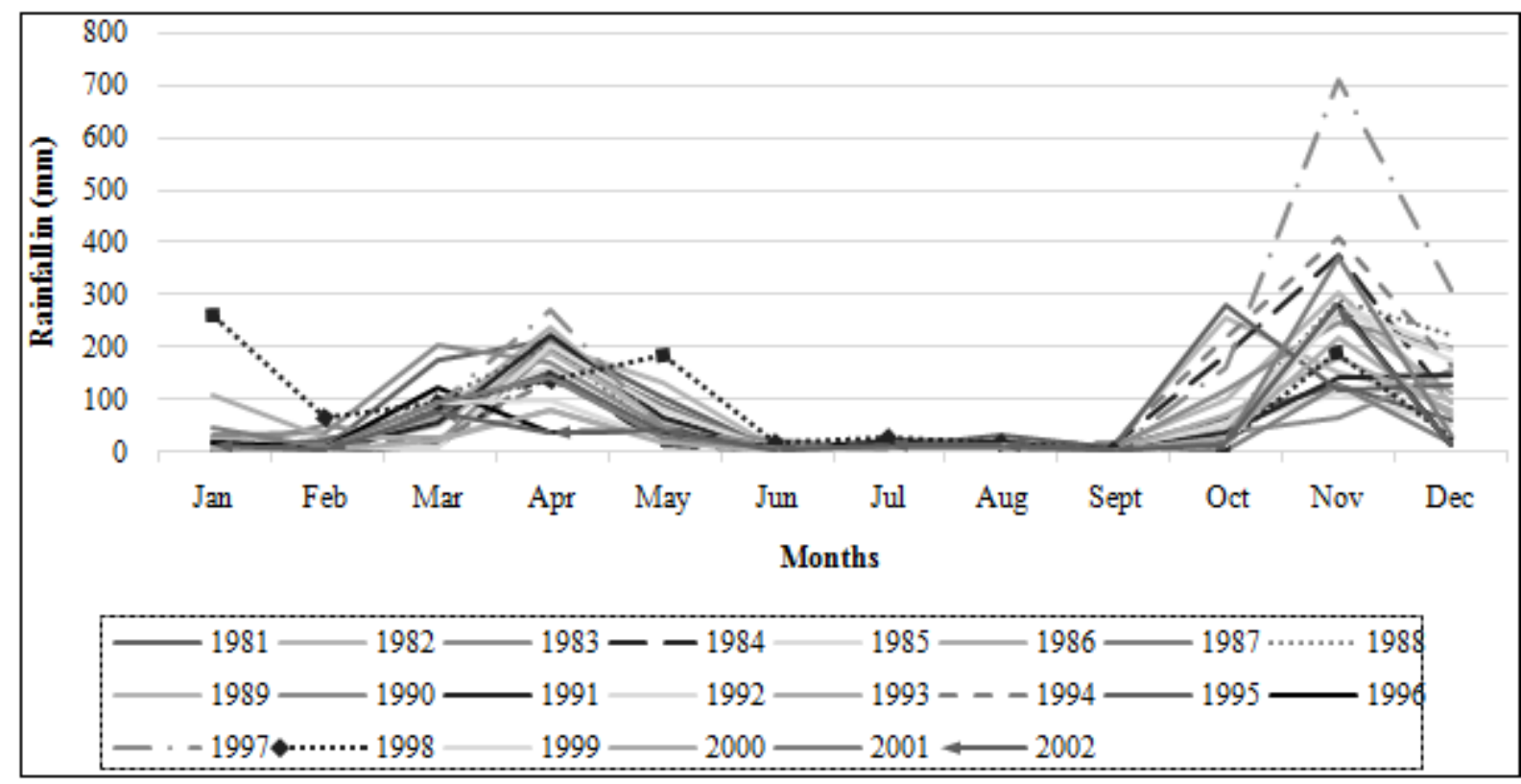

Figure 2: Average monthly Rainfall variability in Nuu region in the period between 1981 and 2002

Figure 2show the seasonal and inter-annual variability in rainfall in the Nuu region for different years. The rainfall pattern is bimodal with rainfall being mainly concentrated within two seasons. The main rainy seasons are March to May (long rains) and October to December (short rains). The two main rainy seasons March to May and October to December are consistent with the rainfall patterns in other parts of Kenya. The three years where the rainfall in the Nuu hills was very high are 1990, 1994, and 1997. The three years when the rainfall received in the Nuu region was low compared to other years are; 1987, 1996, and 2000.The highest rainfall was received in 1997-1998 period and was about $1600 \mathrm{~mm}$.

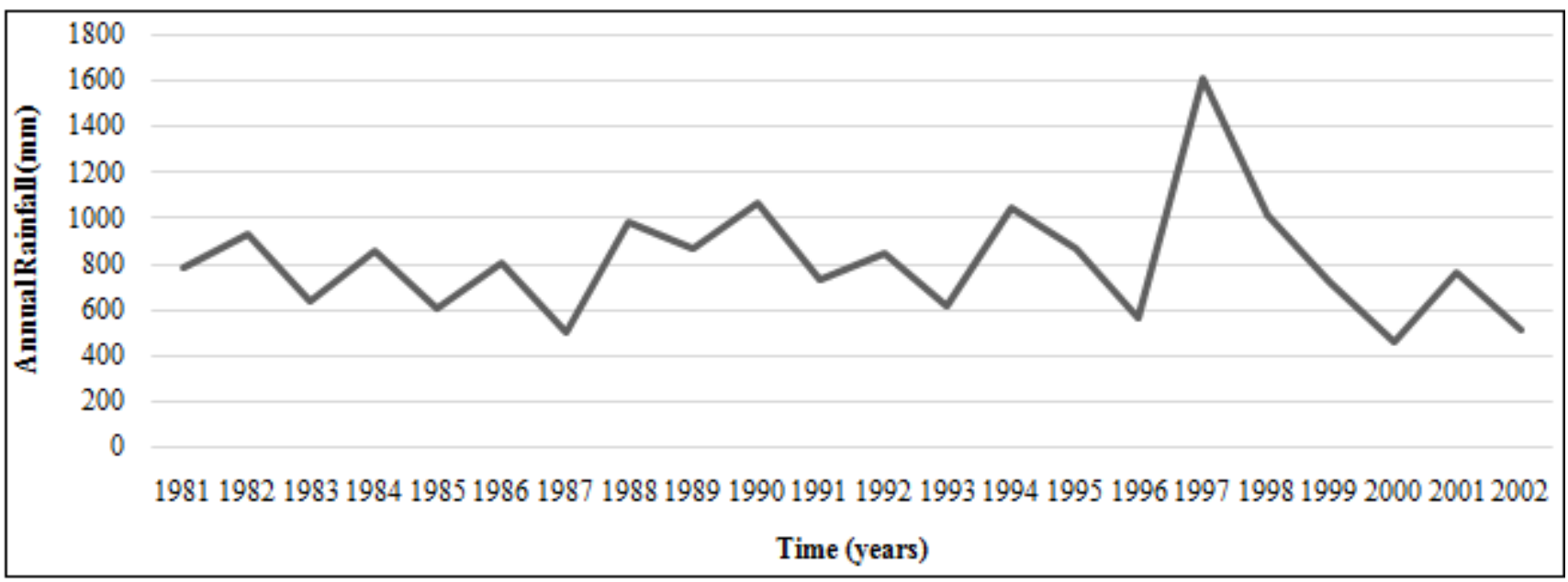

Figure 3: The variability of the annual total rainfall in Nuu region in the period between 1981 and 2002 


\section{International Journal of Science and Research (IJSR) \\ ISSN (Online): 2319-7064}

Index Copernicus Value (2015): 78.96 | Impact Factor (2015): 6.391

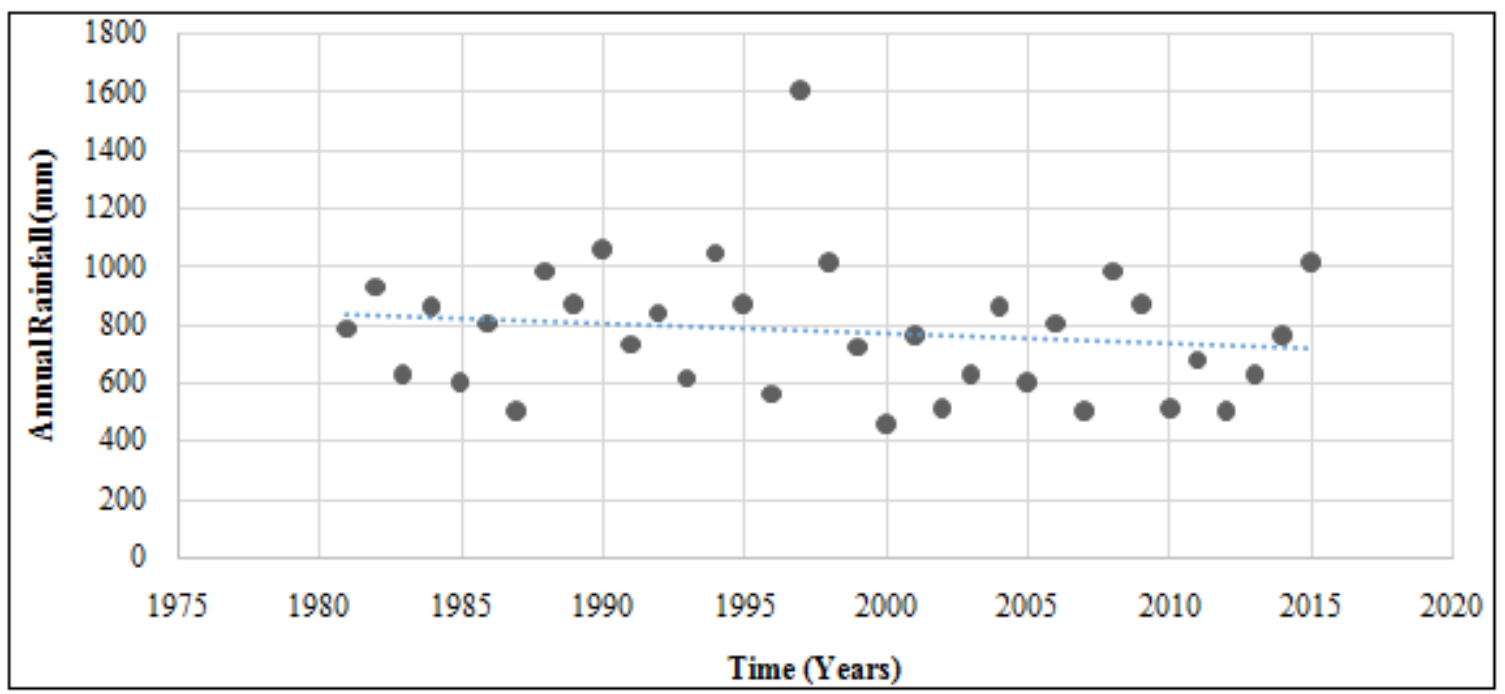

Figure 4: The scattergraph of the total annual rainfall amount in Nuu region for the period between 1981 and 2015

Figures5and 6 shows the pattern of discharge in one of the main springs found in the Nuu Hills catchment in the period between 1986 and 2016 based records obtained in the field. The spring discharges showed a declining trend in terms of the overall production. The periods between 1991 and 1995 and between 1996 and 2000 were characterized by relatively high spring discharges. These relatively high spring discharges are related to the relatively high rainfall that was experienced in the area peaking in the El Nino years of 1997 and 1998 when the mean annual rainfall was $1314 \mathrm{~mm}$ (Figures 2, 3 and 4). However, the effects of high intensity of the rainfall are not clearly evident in the spring discharge data and this was attributed to low rate of infiltration of rainfall to recharge ground water in a degraded forest. There is also a lag between peak rainfall and peak spring discharges that ideally emanates from groundwater aquifers located on the Nuu Hills. Tables 1 and 2 shows the spring's average discharges for dry and wet seasons.

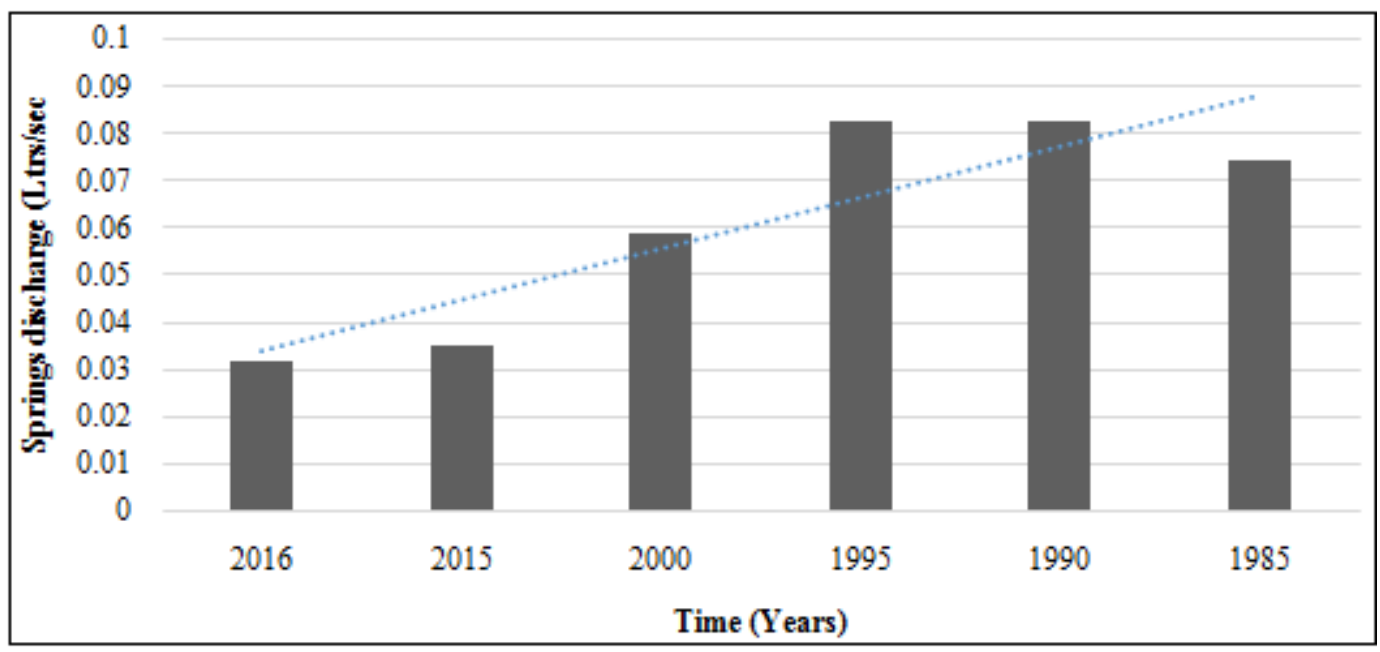

Figure 5: The pattern of spring discharge in Nuu catchment area(Kavui spring) in the period between 1985 and 2016

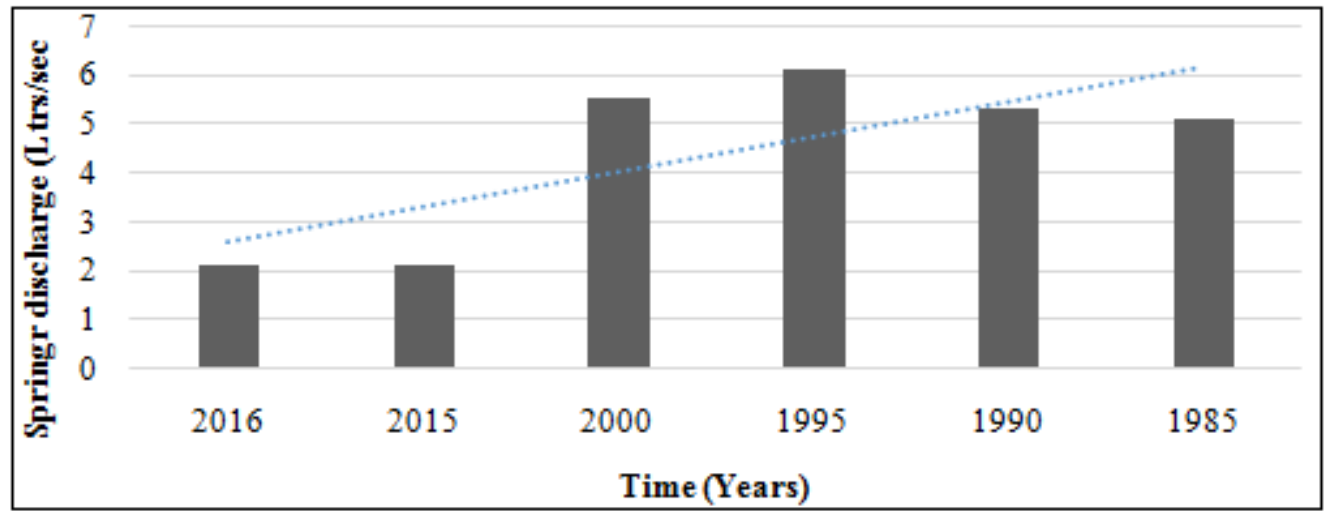

Figure 6: The pattern of spring discharge in Nuu catchment area (Mola spring) in the period between 1985 and 2016

Volume 6 Issue 1, January 2017 www.ijsr.net 


\section{International Journal of Science and Research (IJSR) \\ ISSN (Online): 2319-7064}

Index Copernicus Value (2015): 78.96 | Impact Factor (2015): 6.391

Table 1: Average yield for springs in the Nuu Hills

\begin{tabular}{|c|c|c|c|c|c|c|}
\hline No & Name & Position (GPS) & Altitude $(\mathrm{m})$ & Average yield wet season $(\mathrm{L} / \mathrm{s})$ & Average yield dry season $(\mathrm{L} / \mathrm{s})$ & Remarks \\
\hline 1 & Kavui & $423741 / 9886651$ & 801 & 0.052701 & 0.031621 & Gauged \\
\hline 2 & Makaveti & $424099 / 9886619$ & 868 & 0.21312 & 0.127872 & Gauged \\
\hline 3 & Mola & $424605 / 9887101$ & 726 & 3.621876 & 2.173126 & Gauged \\
\hline 4 & Wikya & $425301 / 9886228$ & 784 & 0.258732 & 0.155239 & Gauged \\
\hline 5 & Kiwani & $422211 / 9885745$ & 970 & 1.71556 & 1.029336 & Gauged \\
\hline 6 & Nuu & $428554 / 9883127$ & 675 & 0.989315 & 0.593589 & Gauged \\
\hline 7 & Kanyululuni & $421609 / 9886397$ & 872 & 0 & 0 & inadequate flow \\
\hline 8 & Kyatuka & $424638 / 9887014$ & 920 & 0 & 0 & Dry \\
\hline
\end{tabular}

Table 2: Average yield for springs in the Mutaitho Hills

\begin{tabular}{|c|c|c|c|c|c|c|}
\hline No & Name & Position (GPS) & Altitude $(\mathrm{m})$ & Average yield wet season (1/s) & Average yield dry season (L/s) & Remarks \\
\hline 1 & Kiviu/Kamutete & $422371 / 9879845$ & 1171 & 0.666445 & 0.399867 & Gauged \\
\hline 2 & Kaunzuu & $422021 / 9877646$ & 863 & 2.172735 & 1.303641 & Gauged \\
\hline 4 & Minyiini & $423397 / 9878933$ & 1062 & 0.082181 & 0.049308 & Gauged \\
\hline 5 & Kasyongala & $424001 / 9879580$ & 952 & 0.740878 & 0.444527 & Gauged \\
\hline 6 & Mutaitho & $423208 / 9879369$ & 1152 & 0 & 0 & inadequate flow \\
\hline
\end{tabular}

\section{b) Variability in land cover}

The analysis of forest cover change was based on the use of Satellite images and Moderate Resolution Imaging Spectroradiometer (MODIS) data for the years 2000 and 2016 (Figures 7a-b and Figure 8a-b). The results showed that was a significant decrease in the forest cover in the Nuu
Hills (Figures 7a-b). The main causes of the reduction in forest cover were felling of trees to open land for farming or charcoal production. The perception of the local community is that the reduction in spring discharges is due to encroachment in the upper areas of the hill including overuse of the spring water and deforestation.
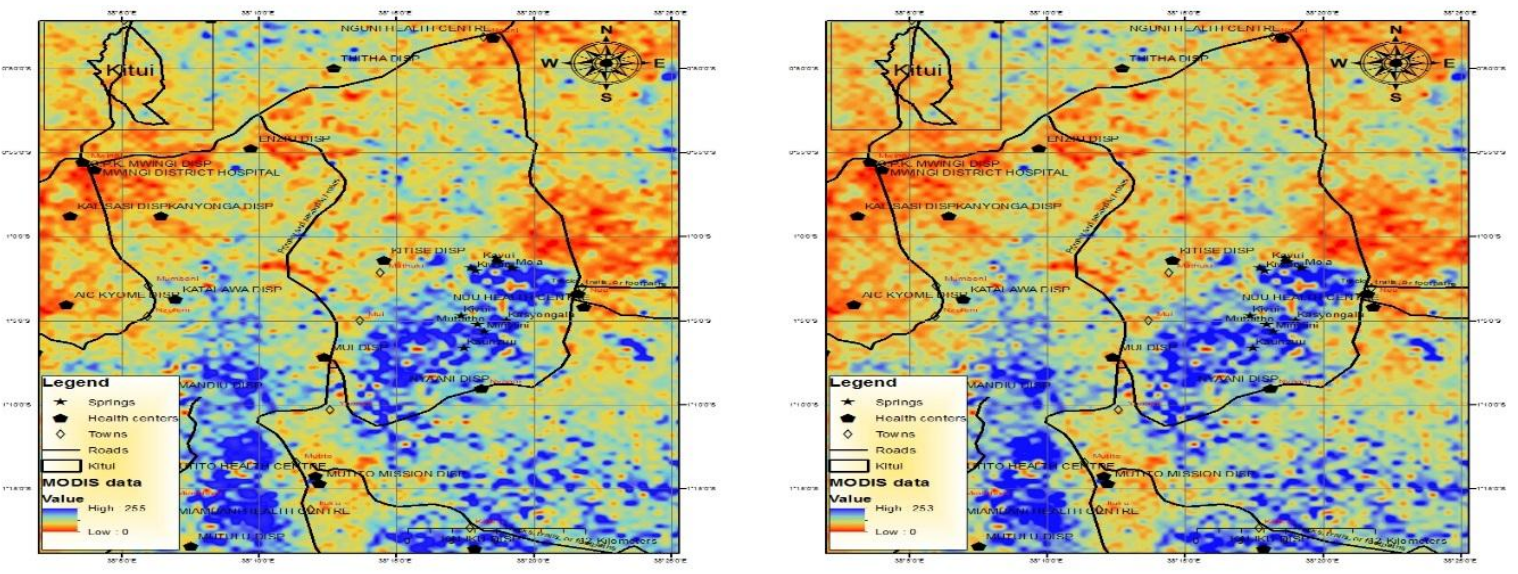

Figure 7a-b: Moderate Resolution Imaging Spectroradiometer (MODIS) for Nuu region for the year 2000 and 2015 respectively showing forest cover concentration in colors

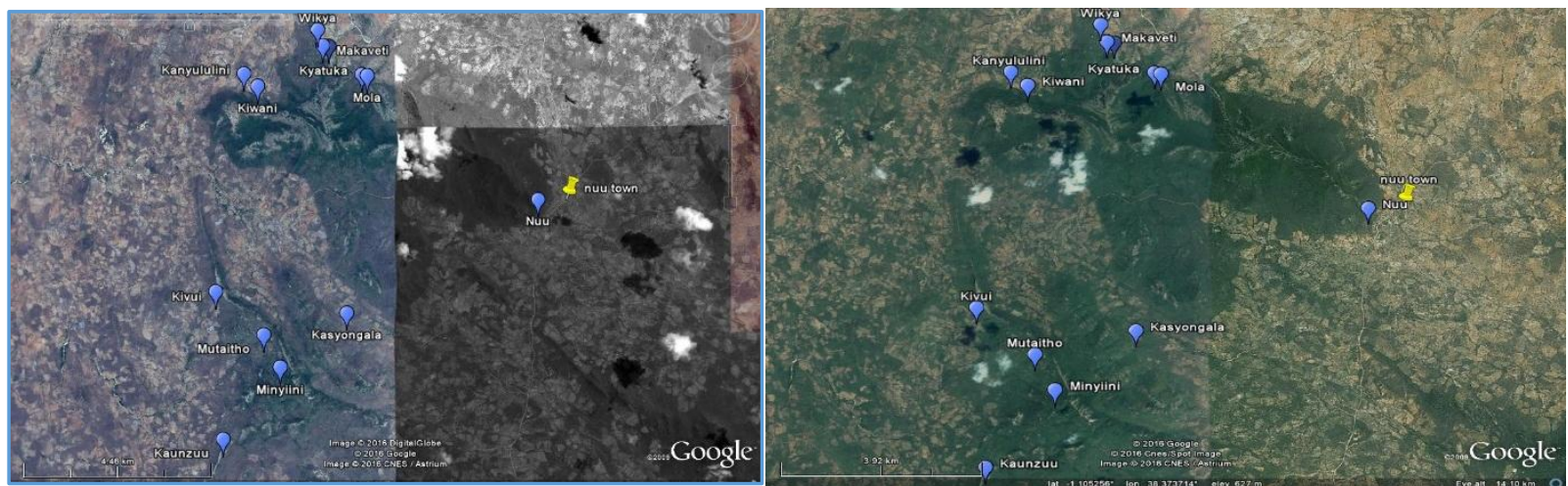

Figure 8a-b: Stellite images of the Nuu Hills region for the years 2000 and 2016 respectively showing vegetation cover on the two hills

The results of questionnaire survey showed that the local communities were not aware of the relationship between the forest cover and the availability of water through spring flows. This was attributed to the community lack of confidence on reforestation initiatives in the area. Land tenure is a challenge as most of the local communities don't

\section{Volume 6 Issue 1, January 2017 www.ijsr.net}




\section{International Journal of Science and Research (IJSR) \\ ISSN (Online): 2319-7064}

Index Copernicus Value (2015): 78.96 | Impact Factor (2015): 6.391

own land and therefore there is no motivation for forest conservation in communally owned public land. The main sources of income for the locals in the area is mainly casual employment, retail business and farming However, the majority of the people residing in the forest area are not involved in any of the above economic activities and majority are involved in other income earning activities such as charcoal production. Local communities have a recollection of the variability of spring's discharges as they also mentioned the years they felt the springs were highly productive as compared to present situation. The local communities thought that springs discharges in period between 1996 and 2000 and also between 1991 and 1995 were $46 \%$ and $42 \%$, respectively. The period between 1980 and 1985 and that between 1986 and 1990 had the lowest spring's discharges according to the respondents. The perception of the local communities in the area seemed to be consistent with the data presented in Figures5 and 6.The reason for relatively high discharges in the earlier years was attributed to the high rainfall experienced in this period and high vegetation cover.

\section{c) Relationship between human activities and spring discharges}

The Table 3 shows the results that were obtained for the relationship between activities practiced within the study area and reasons for springs discharge decline. The correlation coefficient $r$ for the relationship between deforestation rate and spring discharges was 0.25 which is rather low although it indicates positive relationship. The results indicate that there is a direct relationship but this relationship is generally weak. The activities that mostly facilitate deforestation increases also triggers spring flow reduction.

Table 3: The results ofcorrelation analysis of the relationship between activities practiced on in the Nuu Hills and reasons for springs flow reduction

\begin{tabular}{|c|c|c|c|}
\hline & & $\begin{array}{l}\text { Activities } \\
\text { practiced }\end{array}$ & $\begin{array}{l}\text { Reason for } \\
\text { spring flow } \\
\text { reduction }\end{array}$ \\
\hline & Pearson Correlation & 1 & 0.211 \\
\hline & Sig. (2-tailed) & & 0.175 \\
\hline $\begin{array}{l}\text { Activities } \\
\text { practiced }\end{array}$ & $\begin{array}{c}\text { Sum of Squares and } \\
\text { Cross-products }\end{array}$ & 19.860 & 10.837 \\
\hline & Covariance & 0.473 & 0.258 \\
\hline & $\mathrm{N}$ & 43 & 43 \\
\hline & Pearson Correlation & 0.211 & 1 \\
\hline & Sig. (2-tailed) & 0.175 & \\
\hline $\begin{array}{l}\text { Reason for } \\
\text { spring flow }\end{array}$ & $\begin{array}{c}\text { Sum of Squares and } \\
\text { Cross-products }\end{array}$ & 10.837 & 155.077 \\
\hline & Covariance & 0.258 & 3.041 \\
\hline & $\mathrm{N}$ & 43 & 52 \\
\hline
\end{tabular}

Natural forest vegetation is generally characterized by high rates of infiltration compared with other types of land cover with a similar soil base. In natural forest, layers of vegetation protects the top layers of the soils which therefore characterized by good soil structure that allows rapid infiltration of rainfall. However, change from the natural growth to bare land, plantations, grazing land and crop production reduces infiltration rate and the storage capacity of the soil.Forest cover allows the soil underneath to steadily store and then release water slowly. Where an area has been deforested, rainwater tends to flow more quickly into rivers, increasing the likelihood of flash floods. Reduction of the land cover therefore impacts the water cycle which in turn alters spring discharge in semi-arid catchment areas such as Nuu Hills.

\section{Discussions}

\section{a) Rainfall Variability and forest cover}

Rainfall data for the Nuu region shows that there is a significant fluctuation in average rainfall within the selected study time (Figures 3 and 4). There is evidence that rainfall trend in the Nuu region over the period of 22 years has been changing, although there does appear to be a trend in the rainfall pattern for the years between year 1981 to 1998 . Studies done elsewhere (Singh, 1997) shows that springs flow hydrograph are significantly influenced by spatial and temporal variability in rainfall and watershed characteristics which also depend on size and shape of a watershed and its hydrological response is closely linked with storm dynamics. The impacts of rainfall reliability to watershed is significant if the average rainfall input to the hydrological systems and the average time available for this precipitate to be redistributed into the water towers, is well defined(Hobbs, et al., 1991). The semi-arid regions of the world are known for their unreliable rainfall and this has a large impact on the hydrology of the area (Hobbs et al., 1991 and USAID 2000). In Nuu region, rainfall reliability is not constant hence we don't expect the springs flow to be constant (cf. Singh, 1997).

The Moderate Resolution Imaging Spectroradiometer (MODIS) data showed that the forest cover or vegetation cover for the Nuu region was high during the year 2000 period. There has been a rapid decrease in the forest cover which is also evident in the satellite images. There were significant changes in the period between 2000 and 2015 . The main causes of forest cover changes are mainly deforestation in the area due to felling of trees for farming or business of charcoal burning and selling (Chiwa, 2012). The other main cause of the decrease in the forest cover that is currently being noted in the Nuu region is the clearing of land for agricultural purposes. There is also a large proportion of the locals that are involved in livestock grazing activities. The perception of the locals is that the spring discharge is reducing due to encroachment by the local communities near the forest areas, over-use of the spring water and deforestation. These observations are consistence with the information that was obtained from the Moderate Resolution Imaging Spectroradiometer (MODIS) data analysis.

\section{b) Impacts of deforestation in Nuu catchment}

The forested Nuu and Mutaitho hills constitute water towers within Kitui County. The hills are a natural water tower for local communities, storing water during the rainy season and releasing it during the dry season. Climate change and deforestation are thought to be main culprits in the observed increase in the magnitude and frequency of runoff events and reduced base flows. Deforestation is destroying the habitat for vast variety of species, and this is threatening the welfare of the local communities who rely on forests for their livelihoods. Disruption of the forest's role in storing 


\section{International Journal of Science and Research (IJSR) \\ ISSN (Online): 2319-7064}

Index Copernicus Value (2015): 78.96 | Impact Factor (2015): 6.391

and distributing water to outlying areas is disaster waiting to happen.

The analyses of data showed that majority of the people were involved in charcoal production in the catchment area. Thus, charcoal production activities in the area can be considered to be one of the leading causes of forest degradation. Local community seemed not to be aware of the importance of forest cover in sustaining spring discharge. Community without this information does not feel any defect when clearing the forested recharge zone of the springs. In bare land, rain water tends to flow rapidly and infiltration rate is reduced (cf. Herlocker 1979). This reduces base flow in the seasonal rivers. Example is the case of the Enziu river that receives its water from the Nuu catchment. The river only flows during rainy season and rapid flow of the river is characterized by high turbidity due to high rates of soil erosion on the hills. The rapid flow of the river is an indication of the reduction in the infiltration rates of the soils so that most of the water runs off on the surface.

\section{c) Relationship between deforestation and spring discharge}

Natural vegetation is generally characterized by high rates of infiltration compared with other types of land cover with a similar soil base (Aremde, et al, 2012). In natural forest there are usually several layers of vegetation thus the top layers of the soils are well protected and well structured. Change from the natural growth to bare land, plantations, grazing land and crop production reduces infiltration rate and the storage capacity of the soil.Forest cover allows the land underneath to steadily store and then release water. When an area has been deforested, rainwater tends to flow more quickly into rivers, increasing the likelihood of flash floods (Aremde, et al, 2012). Therefore reduction of the land cover may have unforeseen impacts on the water cycle which can in turn alter spring discharges.

The results of questionnaire survey also showed that a woman in the Nuu region earns more income than their male counterparts. The female gender was the majority among the employed category of people in the area. The male gender is not willing to be employed for a monthly income as the forest resource is within their reach and they can engage themselves on charcoal business which is lucrative and has instant pay. The analysis of the questionnaires also showed that the main cause of the deforestation was as a result of the people not being fully aware of the relationship that exists between the forest and the spring discharge. Goudie (2013) found that, for sustainable environmental resource management, local communities needed to be fully involved by awareness creation on sustainable utilization. The results of the study also showed that, the majority of the people involved in livestock grazing and farming had at least attained a secondary level of education. Therefore jobless status is turning youth to other activities which are not environmental friendly like charcoal production. The results also showed that, local communities need to be enlightened on the effects of deforestation and the relationship between water and forest cover (cf. Githae, 2012). From the analysis the results also indicate that people in Nuu region mostly dependent on the springs for their day to day water needs.
This means that the protection of the springs is important for their survival.

The analysis of the questionnaire data also showed that the frequency through which awareness is created among the community was mostly quarterly and the main technique that is used to create awareness is the recognition and applauding of water conservation measures taken by the community. The stakeholders involved in awareness creation activities are mainly the Government of Kenya (GoK), parastatals and the NGOs with the community only accounting for a very small percentage. The respondents in the area also indicated that the main challenge in awareness creation programme was the unwillingness of the community to accept the different initiatives that were being taught to them. The problems faced in awareness creation isa major hindrance in conservation. The initiatives implemented by different government bodies to control deforestation in the area included relocation of settlements from the water towers to down the hills and training the local community on reforestation to reclaim the lost forest resource (cf. Allen, et al., 1985). The analysis on the frequency of implementing awareness campaign showed that the two best frequencies that would work will be monthly or annual awareness campaigns. A further analysis of the initiatives taken by the different stakeholders such as the community, the NGOs and the GoK, showed that community was mostly interested in the initiatives that involved the issue of groundwater recharge as opposed to the issue of protecting the water sources as they are not willing to relocate from the top hills which is the springs recharge zone. Studies done by John (2012) in his research showed that, for sustainable land management community awareness creation needs to be continuous for more understanding of the facts. There is therefore a need to unite the stakeholders offering awareness campaign so as to allow the different campaign team to work in harmony with each other as opposed to each working alone and duplicating the work on the ground. This make the community to lose the meaning of the awareness and concentrate on the allowances awarded to them by each group.

\section{Conclusions}

This study has established that variability in the rainfall amount in the Nuu Hills of Kitui County leads to corresponding variability in the spring discharges. There is however a lag between rainfall and spring discharges which is attributed to the time taken for water to infiltrate in to the soil and the slow rate of ground water flow to the springs. The study found that that there is a decrease in the Nuu Hills forest cover. The main cause of the decrease in forest cover is mainly deforestation which is caused by felling of trees to open land for settlement, farming, livestock grazing and also cutting down of trees for charcoal production. Lack of involvement of the local communities in the conservation of the forests has led to the degradation of the forest. As a result of deforestation, the infiltration rate of water in the Nuu Hills is very slow allowing little water to reach the water table and ultimately slow groundwater recharge which in turn feeds the springs. The effects of deforestation in the Nuu Hills is causing rapid generation of surface runoff due to low rate of infiltration allowing high rates of soil erosion 


\section{International Journal of Science and Research (IJSR) \\ ISSN (Online): 2319-7064 \\ Index Copernicus Value (2015): 78.96 | Impact Factor (2015): 6.391}

which also increased sediments transportation in the Enziu river that receives its water from the Nuu and Mutaitho hills. In order to reduce the degradation of Nuu hills catchment area, the government should consider intensifying civic education through implementation of community awareness campaign focused on forest and water conservation. There is also a need for formulation of policies aimed at controlling detrimental anthropogenic activities such as cultivation on steep slopes, livestock grazing and charcoal burning. The Nuu hills forests should also be gazetted in order to control access to the forest by unauthorized members of the community. The government should also encourage community participation in forest conservation and protection of springs.

\section{Acknowledgement}

I wish to thank the entire fraternity of South Eastern Kenya University for giving me the opportunity to pursue MSc. Degree course in Integrated Water Resources and Watershed Management in the School of Water Resources Science and Technology.

\section{References}

[1] Allen, J. C., \& Barnes, D. F(1985). The causes of deforestation in developing countries. Annals of the association of American Geographers, 75 (2), 163-184.

[2] Aremde F, Tsegaye B. \&Pananjay K(2012). Impact of Human activities on ground water forests of Arb a Minch: A case study from Ethiopia.

[3] Barr, D. J., Levy, R., Scheepers, C\&Tily, H. J(2013). Random effects structure for confirmatory hypothesis testing: Keep it maximal. Journal of memory and language, 68(3), 255-278.

[4] Berry, L (2003). Land degradation in Ethiopia: Its extent and impact. Commissioned by the GM with WB support, 2-7.

[5] Brovkin, V., Claussen, M., Driesschaert, E., Fichefet, T., Kicklighter, D., Loutre, M. F \&Sokolov, A(2006). Biogeophysical effects of historical land cover changes simulated by six Earth system models of intermediate complexity. Climate Dynamics, 26 (6), 587-600.

[6] Brown, J., W. Jepson, J. Kastens, B. Wardlow, J. Lomas \& Price, K (2007). Multitemporal, Moderate-SpatialResolution Remote Sensing of Modern Agricultural Production and Land Modification in the Brazilian Amazon. GIS \& Remote Sensing 44, no.2 (6): 117-148. doi:10.2747/1548-1603.44.2.117.

[7] Chawla, A., Yadav, P. K., Uniyal, S. K., Kumar, A., Vats, S. K., Kumar, S\& Ahuja, P. S(2012). Long-term ecological and biodiversity monitoring in the western Himalaya using satellite remote sensing. Current Science (Bangalore), 102(8), 1143-1156.

[8] Chiwa, R(2012): Effect of land use and land cover changes on hydrology of Weruweru-Kiladede subcatchment in Pagani river basin in Tanzania page 24-41

[9] Eng, J. (2003). Sample Size Estimation: How Many Individuals Should Be Studied? 1. Radiology, 227(2), 309-313.

[10]FAO (2006a). towards a new generation of watershed management programmes and projects. Presented at the 25 th session of the Working Party on the Management of Mountain Watersheds, Salzburg, Austria, 24-26 April. Available at: www.fao.org/ forestry/site/36263

[11]FAO (2006b). The new generation of watershed management programmes and projects. FAO Forestry Paper No. 150. Available at: www.fao.org/docrep/009/a0644e/ a0644e00.htm

[12] Gachari, D. N. K. M. K., Mary, W., \&Mungai, E(2011). Mapping groundwater potential in Kitui District, Kenya using geospatial technologies.International journal of water Resources and Environmental Engineering, 4(1), 15-22.

[13] Goudie, A. S (2013). The human impact on the natural environment: past, present, and future. John Wiley \& Sons.

[14]Hansen, M. C., Potapov, P. V., Moore, R., Hancher, M., Turubanova, S. A., Tyukavina, A. \&Kommareddy, A(2013). High-resolution global maps of 21st-century forest cover change. Science, 342(6160), 850-853.

[15]Herlocker, D (1979). Project 3: Impact of human activities and land use practices on grazing lands. Nairobi, Kenya UNEP: Integrated Project in Arid Lands (IPAL).

[16] Hobbs, R. J\& Mooney, H. A (1991). Effects of rainfall variability and gopher disturbance on serpentine annual grassland dynamics. Ecology,72(1), 59-68.

[17] House, J. I., Colin Prentice, I \& Le Quéré, C (2002). Maximum impacts of future reforestation or deforestation on atmospheric CO2. Global Change Biology, 8(11), 1047-1052.

[18] Imbernon, J (1999). Pattern and development of landuse changes in the Kenyan highlands since the 1950s. Agriculture, ecosystems \& environment, 76 (1), 67-73.

[19] Justice, C. O., Vermote, E., Townshend, J. R., Defries, R., Roy, D. P., Hall, D. K\&Lucht, W(1998). The Moderate Resolution Imaging Spectroradiometer (MODIS): Land remote sensing for global change research. IEEE Transactions on Geo-science and Remote Sensing, 36(4), 1228-1249.

[20]Laws, R. M (1970). Elephants as agents of habitat and landscape change in East Africa. Oikos, 1-15.

[21]Lefsky, M. A., Cohen, W. B., Parker, G. G\& Harding, D. J(2002). Lidar Remote Sensing for Ecosystem Studies Lidar, an emerging remote sensing technology that directly measures the three-dimensional distribution of plant canopies, can accurately estimate vegetation structural attributes and should be of particular interest to forest, landscape, and global ecologists. BioScience, 52(1), 19-30.

[22] Lvovitch, M. I(1977). World water resources present and future. Ambio, 13-21.

[23] Pellikka, P.K., Lötjönen, M., Siljander, M., \& Lens, L(2009). Airborne remote sensing of spatiotemporal change (1955-2004) in indigenous and exotic forest cover in the Taita Hills,

[24] Singh, V.P(1997). Effect of spatial and temporal variability in rainfall and watershed characteristics on stream flow hydrograph. Hydrological Processes, 11(12), 1649-1669.

[25] Tambe, S., Kharel, G., Arrawatia, M. L., Kulkarni, H., Mahamuni, K \&Ganeriwala, A. K (2012). Reviving dying springs: Climate change adaptation experiments 


\section{International Journal of Science and Research (IJSR) \\ ISSN (Online): 2319-7064}

Index Copernicus Value (2015): 78.96 | Impact Factor (2015): 6.391

from the Sikkim Himalaya. Mountain Research and Development, 32(1), 62-72.

[26] UNEP (2009). Towards sustainable production and use of resources: assessing biofuels. UNEP/Earthprint.

[27] USAID (2000). Kenya Strategic Plan: environmental Threats and Opportunities Assessment. Natural Resource Management and Development Portal. 1-40

[28] Van Loon, A. H., Schot, P. P., Bierkens, M. F. P., Griffioen, J \&Wassen, M. J(2009). Local and regional impact of anthropogenic drainage on fen contiguity. Hydrology and Earth System Sciences, 13(10), 1837-1848.

[29] WRI(2007). World Resources Institute, Department of Resource Surveys and remote Sensing, Ministry of Environment and Natural resources, Kenya, Central Bureau of Statistics, Ministry of Planning and Development, Kenya; and International Livestock Research Institute: Nature's Benefits in Kenya: An Atlas of Ecosystem sand Human Well-Being, World Resources Institute, Washington, DC, and Nairobi. 